\title{
Was John Paul II an Apologist of Christianity?
}

\begin{abstract}
The paper tries to answer the question whether John Paul II was an apologist of Christianity. Moving along scholastic methodology, the paper progress along three stages, exploring a negative statement (videtur quod non), justifying a positive assertion (sed contra), to formulate a conclusion (ergo). Through this methodology the paper argues that Pope John Paul II was the defender of Christianity. This methodology allows thorough study of the highlights of the pontificate of this Great Pope and on the basis of counter-points to bring out a more clear answer to the research question.
\end{abstract}

\section{Keywords}

Pope John Paul II, apologist, defender of Christianity.

\section{Introduction}

As from $1^{\text {st }}$ of May 2011 John Paul II has been recognized by the universal Church as "Blessed". For almost 27 years of his pontificate, he was recognized, in accordance with Church's tradition. John Paul II was accorded the titles of "the Bishop of Rome", "Successor of the Prince of the Apostles", "the Supreme Pontiff of the Church", "Patriarch of the West", "the Primate of Italy", "Archbishop and Metropolitan of the Province of Rome", "the Head of the Vatican State", "the servant of the servants of God". But these are not all the titles through which

${ }^{1}$ See Annuario Pontificio per l'anno 2002, Città del Vaticano 2002, p. 23. Before he was granted this title, during the ceremony of beatification on St. Peter's Square, and since the beginning of the beatification and canonization process, he was recognized as "Servant of God", 
he was recognized. As a Pope, Theological tradition recognized in him "the successor of St. Peter", and "the visible head of the Church", yet his biographer also recognized through such titles as: "the witness of hope"2, "pastor”, ,Man of the Century"4. Immediately after his death those, who have spoken out in public, in a specific way competed with each other to construct new and more original titles for him. The Deutsch paper Der Spiegel name him as "Pope of the millennium"s. London's The Observer wrote about "the man who changed the world". George Bush named him as "the master of human liberty", and Jaques Chirac spoke of "the unique supreme pastor". Mikhail Gorbachev spoke of him as "the greatest humanist on our globe". Henry Kissinger said: "it is possible that he is the greatest man of the XX century" and The Dalai Lama called Pope Wojtyła "an incredible man". Into the mosaics of these titles we can add one more, which he said himself, during one of his numerous apostle's pilgrimages to Africa, that he is "the voice of the voiceless"?

This collection of titles - especially those appearing after the death of John Paul II, and on the occasion of subsequent anniversaries, or related events, can be surely increased. Though their collection and analysis could picture this pope in an interesting way, and illustrate his pontificate, we are interested in a different title, namely the title of "apologist" which can be understood as, "the defender of the Church", "the defender of Christianity". That title is closely related with Christianity itself, and it appeared many times within its history. In this sketch we would like to consider if John Paul II can be called "the apologist of Christianity". In other words, we would like to know if John Paul II really deserves the title "defender of Christianity"? So we ask: Was John Paul II, Christian and Shepherd of the Universal Church, who had the greatest influence on the shape of Christianity in recent decades of the XX c., also its defender?

and also after the issue of the decrees on his heroic virtues - as "the venerable servant of God". These are the titles which were given to him after after his departure to the Father's home on $5^{\text {th }}$ of April 2005. Since that memorable October 16, 1978, when the College of Cardinals - the electors, chose the archbishop of Cracow, Karol Wojtyła, as the $264^{\text {th }}$ successor of St. Peter.

${ }^{2}$ See G. Weigel, Świadek nadziei. Biografia papieża Jana Pawła II, Kraków 2000.

${ }^{3}$ See, B. Lecomte, Pasterz, Kraków 2006.

${ }^{4}$ See J. Kwitny, Man of the Century. The Life and Times of Pope John Paul II, New York 1997.

${ }^{5}$ See P. Seenwald, Jezus Chrystus. Biografia, Kraków 2011, p. 15.

${ }^{6}$ See B. Lecomte, Pasterz, Lc., p. 6.

${ }^{7}$ See G. Weigel, Świadek nadziei, Lc., p. 857. Those, who better know this pontificate and had a chance to meet John Paul II closer probably agree that this was the title accurately characterizing the pope and also pleasing to him (maybe as much as "the servant of the servants of God"), in contrast with the pathetic titles, which was given to him, especially after his death. 


\section{It seems not}

The first thought which comes when answering this question is negative, or negative subdued with the statement "it seems". Analogically to the famous, arising from the scholastic method of St. Thomas Aquinas: videtur quod non. So it seems not. But why?

\subsection{From the definition and history of apology}

Apology is a defense. A term "apology" in the meaning of defense of Christianity, comes from Greek: apologéomai, which means "to speak in one's defense", "defend oneself", "utter defense". For that is apologia which means objectively "defense" in the sense of "defensive speech", and verbally "defend", "defend oneself". Both the first and second form is present in the New Testament (See Lk. 12,11; 21,14; Acts 19,33; 22,11; 24,10; 25,8.16; 26,1-2.24; Gen. 2,15; 1 Cor. 9,3; 2 Cor. 7,11; 12,19; Phil. 1,7.16; 2 Tm. 4,16; 1 P. 3,15).

Already in early Christianity (II-III century) there are the apologists, the writers who set out to defend Christianity against the Jews and Gentiles. Their apologies are usually a form of dialogue or voice his own defense. Among the most famous apologists in the early Christianity are: St. Justin, St. Clement of Alexandria, Origen in the East and Tertullian and St. Cyprian in the West. The next centuries (IV-V), are those formidable defenders of Christianity as: St. Athanasius the Great in the East and St. Augustine in the West ${ }^{9}$. The early Christian apologists were recording the unfair charges of the pagans about Christianity and they unmasked the absurdity of polytheism ${ }^{10}$. In the confrontation with Jews, they referred to the Old Testament to prove that Jesus was the promised Messiah ${ }^{11}$.

Even though the situation of Christianity changed considerably after the year 313 a.d., the need for apology never declined. In The Middle Ages apologies were created to confront Judaism and Islam. The most important defenders of that time were: St. Isidore of Seville, St. Bede the Venerable, St. Albert the Great and St. Thomas Aquinas. Considering the Modern age (XVI-XVII c.)

\footnotetext{
${ }^{8}$ See R. Popowski, Wielki Stownik Grecko-Polski Nowego Testamentu, Warszawa 1995, p. 65.

9 See E. Florkowski, Apologeci chrześcijańscy, in: Encyklopedia Katolicka, vol. 1, F. Gryglewicz, R. Łukaszyk, Z. Sułowski (eds.), Lublin 1985, columns 776-777.

${ }^{10}$ See ibid., column 776.

11 See R. Łukaszyk, Apologie chrześcijaństwa, in: Encyklopedia Katolicka, vol. 1, F. Gryglewicz, R. Łukaszyk, Z. Sułowski (eds.), Lublin 1985, column 788. See also: K. Kaucha, Apologia chrześcijaństwa, in: Leksykon Teologii Fundamentalnej, M. Rusecki (eds.), LublinKraków 2002, p. 89-92.
} 
there was confrontation with the Reformation Movement, mainly led by Card. Stanislaus Hosius and St. Robert Bellarmine. Then there was the confrontation with rationalism and deism (XVIII-XIX c.), the defense of Christianity by such philosophers as: Blaise Pascal, Jacques Bénigne Bossuet, François René de Chateaubriand and bl. John Henry Newman ${ }^{12}$.

Among the apologists of early Christianity, and in later centuries there are bishops, theologians and laity, but there was no pope. Perhaps their role was differently seen? Perhaps there was another mission, given by Christ to Peter, and his successors, Bishops of Rome?

\subsection{From the nature of the mission of the successor of St. Peter}

Three gospel scriptures describe the mission which was given to St. Peter by Jesus Christ. Firstly, it is a fragment of the description of the event at Caesarea Philippi, in which the power of the keys was granted to Simon Peter (see Mt 16,17-19). The second fragment is found in St. Luke's gospel, in the appeal made by Christ at the last Supper to strengthen the communities (see Lk 22,31-32). Finally, we find Peter being given the pastoral mission during the special Easter revelation in the Gospel of St. John (see J 21,15-19).

Peter, as the one who receives the power of the keys, has to open the reality of the kingdom of heaven to ordinary people. He has to contribute to that Church, reflecting the humility and compassion of the Christ, which will mark and the leaven of the kingdom among the people. In the same verse the power of binding and loosing are mentioned. According to rabbinic tradition, these refer to deciding that some science is compatible or incompatible with the truth of the Gospel, determining the admissibility or inadmissibility of an act in view of the kingdom of God, to forgive or retain sins, and the exclusion or inclusion of the Church ${ }^{13}$.

St. Luke is the only Evangelists who narrates the words of Jesus, addressed to Peter, during the Last Supper. He is to strengthen his brothers in faith, being protected from losing his own faith, thanks to the prayer of Jesus. Peter has to teach, proclaim the words of Jesus, give courage and call to fidelity.

On the other hand, during the christophany on the Sea of Galilee, St. Peter receives a function of the shepherd of the whole Church. His mission and its core is a complete and self-sacrificing love of Christ. He is entrusted to lead the sheep to the fertile pastures and protect them in the face of danger. This means caring

\footnotetext{
${ }^{12}$ See ibid., columns 790-791.

${ }^{13}$ See H. Seweryniak, Świadectwo i sens. Teologia fundamentalna, Płock 2001, p. 445.
} 
about teaching enlightening and sanctifying word, the sacraments, and guard against false doctrine and breakage ${ }^{14}$.

The mission of Peter and his successors is to safeguard and faithful transmission of the faith traditions, strengthening the brethren in the faith and concern for the sanctity and preservation of unity entrusted to their love of Christ Church.

\subsection{From the priorities of John Paul II}

The key moments of John Paul's II pontificate - the events, documents, speeches - all show his priorities. These seem to suggest that the outlook and the decisions of the Pope, exceeds by far the mentality of a concern for the defense of a besieged fortress. He emphasized many times how much he owed to the Second Vatican Council as it was the Council of a great opening of the Church to the world, to other religions, other catholic faiths. It was the Council of great trust.

It is therefore not surprising that in addition to concern for the Church, his great concern was for humanity and for the world. One could say that his concern was not so much Christianity (as such), but the man whom he regarded as the primary and fundamental way for the Church ${ }^{15}$. The first concern of John Paul II was the human person. Since he believed that Christ, "has united Himself in some fashion with every man" and that "the truth is that only in the mystery of the incarnate Word does the mystery of man take on light"16, so at the inauguration of his pontificate he cried out: "Do not be afraid! Open the doors to Christ." In his first encyclical, he wrote: "Accordingly, what is in question here is man in all his truth, in his full magnitude. We are not dealing with the «abstract» man, but the real, «concrete», «historical» man. We are dealing with «each» man, for each one is included in the mystery of Redemption"17. So he wanted to reach all corners of the earth and meet with each person to show him the way of happiness in Christ. In his attitude he resembled bl. John XXIII - "pastor of the world". So, he wanted everybody to come and meet Christ.

John Paul II wanted to be, and in fact was, the voice of all those, who are voiceless - the unborn, the rejected, the outcasts of society, the abused and exploited, enslaved and the poor - no matter what their religion or faith. He

${ }^{14}$ See ibid., p. 447.

${ }^{15}$ See John Paul II, Encyclic Redemptor hominis, No. 14.

${ }^{16}$ The Second Vatican Council, Pastoral Constitution on the Church in the modern World Gaudium et spes, No. 22. John Paul II echoed the thoughts of the Council in his first encyclical (see John Paul II, Encyclic Redemptor hominis, No. 13).

${ }^{17}$ John Paul II, Encyclic Redemptor hominis, No. 13. 
demanded human rights, especially to life and liberty, including religious freedom, and rights of peoples to self-determination.

Among the texts about the primacy of St. Peter and his successors, he preferred to recall most often, the script written by St. Luke: "Simon, Simon! Look, Satan has got his wish to sift you all like wheat; but I have prayed for you, Simon, that your faith may not fail, and once you have recovered, you in your turn must strengthen your brothers" (Lk 22,31-32). In those words, most of all, he strengthened his brothers in faith and took care of the unity of Christ's followers. Also, if you look at John Paul II through the prism, it seems that he was concerned not only about Christianity, but Christians (all Christians); not for the survival of the idea, but the realization of the ideal. That is why so often choose to travel (one calculates that during his pontificate he spent about a total of two years outside the Vatican!). He met thousands of people in person and delivered countless speeches. In this way so many followers of Christ were beatified and canonized $^{18}$.

He was more like a prophet - like Moses (although he didn't like this comparison) - who sets out goals, and presides. Everybody, no matter if they asked for it or not, were included in his prayers. His ideas of "geography of prayer the Pope" and file cards with prayers and intentions written on them, on his kneeling-chair, are widely known. In his prayer is - again, like Moses - between God and people begging for mercy ${ }^{19}$.

\section{But still}

On our methodological path, following St. Thomas Aquinas, we have said: videtur quod non, now we say: sed contra. So after the "it seems not" stage, comes the time to introduce and explain the opposite sentence "but still".

\subsection{All Christians are called to defend their faith}

St. Peter has called the Christians in Asia Minor to: "always have your answer ready for people who ask you the reason for the hope that you have" (1 Pt 3,15). The call of St. Peter, though pointed directly at the recipients of this letter, affects all followers of Christ, no matter when or where among the society they live. Today, the Christians are also called to prove their hope, connected with Jesus

${ }^{18}$ In total, John Paul II proclaimed 482 saints and 1338 blessed (see S. Karczewski, Jan Pawet II. Encyklopedia Pontyfikatu 1978-2005, Radom 2005, s. 445 and 491).

${ }^{19}$ Nie lękajcie się!. André Frossard. Rozmowy z Janem Pawłem II, Rzym 1982, p. 265. 
Christ. If, therefore, every member of the Church is summoned to defend the faith and justify his hope, which fills him with life, this is even more important for him who is the first among them as "the servant of the servants of God".

Christians are disciples of Christ, that is persons who live by faith, hope and love. These persons are united with Christ through Baptism and receive a share in his priestly mission, teaching and royalty. Their life has to give to God "spiritual worship", to be witnesses of Jesus, "so that the power of the Gospel might shine forth in their daily social and family life" and conquering the reign of sin in himself, to serve Christ in his fellow men ${ }^{20}$.

The best and most effective defense of the faith and the reasons for the hope is the testimony of a Christian life. Management of the faith in all circumstances of life, especially in elections and in making important or less important decisions, is the way to an authentic certificate. Build your life on hope, as the firm and enduring basis and inspiration to hope, especially when a lot or everything seems to contradict her, makes the Christian witness is even more readable. Finally, the everyday life of love for God and neighbor, especially the love of enemies, is a sine qua non, and the most beautiful crowning testimony.

This supreme level of the evidence is discovered in the lives of many saints. Christian faith, hope and love, have filled their lives in such a way that it is not only impossible to separate one reality from another. I, but it is impossible to understand one without the other since their lives, in all its dimensions, become lives of faith, hope and love.

Undoubtedly of Bl. John Paul II one may easily discern this kind of defense of the faith and the justification of hope that flows from it. He was the bishop and the Pope, but above all he was a Christian in close and intimate union with Christ. Faith, hope and love were the breath of his life, filling the priestly and royal mission of teaching received from Christ and the highest form of Christian witness to Christ and submitted to those who demanded the reason for the hope which animated him (cf. 1 Pt 3.15).

\subsection{The Pastor, not only feeds, but also defends}

John Paul II is therefore an example of a Christian who was always ready to justify the hope that he lived. But this Christian received from Christ a special mission in the Church. Firstly, he became the archbishop of Cracow, next as a bishop of Rome, the supreme pastor of the Church. Besides the tasks connected with being a Christian there came the duty of being the pastor. The

${ }^{20}$ See The Second Vatican Council, Dogmatic Constitution on the Church Lumen gentium, No. 34-36. 
field of responsibility was greatly enlarged from that moment. The person, who is a pastor - poimen - has to feed, guard, watch, and defend (see J 21,15-19), but he must also be ready to give his life (see $\mathrm{J} 10,11-13$ ).

John Paul II defended the sheep and the flock of Christ against the evil and the evil. Rather, he was ready to "the powerful of this world", rather than allow it to believers met by any injury or been exposed to any error. He was aware that it often takes a tough mission, and is faced with great challenges, but they never retreated. Some visits, meetings and speeches require tremendous courage. It seems that the more important and the more difficult the task, the more helpless and left to their own people were.

The wider look on the pontificate of the Polish Pope allows us to see the specific method of defense and justification at the same time, which dominates in speeches. It is the presentation and patient justifying the character of Christianity and the Christian faith in context of modern times. John Paul II learned to speak like that probably during the Council, when speeches were like that, and which - as Karol Wojtyła explained himself - had an enormous influence on him. The example of this method is the teaching of the Pope, published in tens tomes of Insegnamenti. What is stunning here is, on the one hand, the consequence in practicing this method, and on the other, his activity of a Pope as a teacher. One could say that he was relentless in his mission.

In this context, we should point special attention to the Catechism of the Catholic Church, published in 1992 by direct will John Paul II. Firstly, it is a great vademecum for the Christians on "how to be a Christian", and secondly, a marvelous positive presentation - defense and justification of Christianity to the modern world and for those who are "outside".

Similar, though in a much more personal tone, is his book-interview Crossing the Threshold of Hope ${ }^{21}$, where through his method the Pope speaks clearly on the place of Christianity in the modern world. The book, judged as a key to decipher and interpret the teaching of John Paul II, shows not only his mind but also heart ${ }^{22}$. This is why, this work should be considered as the key work of John Paul II, in which he justifies Christianity, explains and defends it. It is a typical example of "Pope's Wojtyła style", who patiently, but shortly, explains (it is almost one hundred questions in thirty three issues), the fact of Christianity in the context of modern times.

${ }^{21}$ See Przekroczyć próg nadziei. Jan Pawet II odpowiada na pytania Vittorio Messoriego, Lublin 1994.

${ }^{22}$ See V. Messori, Zamiast wprowadzenia, in: Przekroczyć próg nadziei, Lc., p. 18. 


\subsection{The fields of expertise, in which he distinguished himself with great activity}

The subjects mentioned in, counting in thousands, speeches of John Paul II are as many, or even more. One can try to categorize them in the following way, issues about faith, issues connected with the realm of morality-ethics, issues dealing with the human dignity and rights and finally the historic issues ${ }^{23}$.

If it is about the issues connected with faith, the elements of its defense and justification, we can find in the speeches of John Paul II in defense of some misunderstood truths, e.g. Revelation, the Church, the Cross or the Resurrection. In that field one needs to see those sentences of the pope where he defends living Christianity as a religion that has something to say to the modern human, and to the modern culture. But also the sentences about ecclesiastical discipline, which is flowing from faith, and the organization of the ecclesiastic life. And these are: the defense of the celibacy of the clergy, and the rule not to grant Ordination to women $^{24}$. Finally the specific form of defense of the faith, and the mind is the encyclical Fides et ratio, in which the pope writes about the relations between the faith and the mind ${ }^{25}$.

The engagement of John Paul II in the sphere concerning the human life, in the issues of bioethics and moral-ethical ways of proceeding was exceptional. The response of ways the pope on the Atlantic civilization crisis and the breakdown of the basis of general human values, was a strong and uncompromising defense of the right to life of every human from the beginning till the natural death. The pope was recognized there as a true follower of St. Paul, insisting, courageously and patiently showing error convincing to fundamental values (cf. $2 \mathrm{Tm} \mathrm{4,2).}$ John Paul II was involved in the defense of the ethical foundations of genetic experiments opposing any abuse in this regard and in order to defend the issue in the sphere of sexual morality ${ }^{26}$.

John Paul II showed also enormous engagement in regards to the issue of defense of human rights and dignity, as we have stated earlier. In this regard, he was a defender of the Christians in the conversations with the leaders of the

${ }^{23}$ On the elements of apology in teachings of John Paul II, see K. Kaucha, Elementy apologii Kościoła w nauczaniu Jana Pawła II, the message submitted during the VII ${ }^{\text {th }}$ Congress of the Association of Fundamental Theologists in Poland (Gdansk, 21-23 ${ }^{\text {rd }}$ of September 2011). The text not published yet. We have borrowed some thoughts from this meeting.

${ }^{24}$ See more on that topic: John Paul II, Apostolic letter Ordinatio sacerdotalis (1994).

${ }^{25}$ See John Paul II, Encyclic Fides et ratio (1998).

${ }^{26}$ John Paul II is the first pope in history, who wrote two encyclicals on moral issues: Veritatis Splendor (1993) and Evangelium vitae (1995). 
Islamic nations ${ }^{27}$. We would like to point to his involvement in the debate on social issues, which has issued three encyclicals ${ }^{28}$. In the first, especially important for the pope, he defended the rights of workers.

John Paul II spoke also on historical issues. His speech in particular about burdening the Church responsible for the Inquisition and ownership of the Shoah. The line of defense of the Church, adopted by him, was based on showing the wider context of those historic events, especially with regarding the inquisition and the needs of individual examination of the eventual responsibility of some Christians for their attitudes towards the Jews before and after the Second World War. The pope decidedly defended his predecessor, Pope Pius XII, by showing his engagement in saving Jews ${ }^{29}$.

\section{Conclusion}

In the scholastic lecture, the conclusion is introduced through the short ergo, which can be expressed through our "so". After we have introduced the arguments "against" - videtur quod non, and "for" - sed contra, it is suitable for us to conclude: ergo John Paul II was an apologist of Christianity.

Though in recent centuries, the biggest apologists weren't and aren't from the clergy - on the contrary, it seems that the laity is performing the defense of Christianity more efficiently - John Paul II can be considered as the biggest defender of Christianity in the second half of XX c.. In that time there was nobody else who would with such determination defend every human and every Christian. One could say that he protected the Christianity - in the meaning of "justifying the hope, which was in him" - with his word and all his life. His life, and, at the end of it, through his suffering and by embracing death, he was the best defense of Christianity.

${ }^{27}$ See L. Accattoli, Karol Wojtyła. Człowiek końca tysiaclecia, Wrocław 1999, p. 302-309.

${ }^{28}$ See John Paul II, Encyclicals: Laborem exercens (1981), Sollicitudo rei socialis (1987) and Centesimus annus (1991).

${ }^{29}$ See approved by John Paul II document of the Commission for the Religious Contacts with the Judaism, Pamiętamy: Refleksje nad Szoah (1998). 


\section{Bibliography}

Accatoli L., Karol Wojtyła. Człowiek końca tysiąclecia, Wrocław 1999.

Accatoli L., Kiedy papież prosi o przebaczenie. Wszystkie “mea culpa” Jana Pawła II, Kraków 1999.

Dulles A., Blask wiary. Wizja teologiczna Jana Pawła II, Kraków 2003.

Jan Paweł II, Przekroczyć próg nadziei, Lublin 1994.

Kwitny J., Man of the Century. The Life and Times of Pope John Paul II, New York 1997.

Lecomte B., Pasterz, Kraków 2006.

“Nie lękajcie się!”. André Frossard rozmowy z Janem Pawłem II, Città del Vaticano 1982.

Weigel G., Świadek nadziei. Biografia papieża Jana Pawła II, Kraków 2000. 
